\title{
Effect of Mercury Transfer from Producer to Consumer in a Marine Environment
}

\author{
AH Bu-Olayan*, BV Thomas \\ Department of Chemistry, Kuwait University, Khaldiya Campus, Kuwait
}

Received: 11 April 2017

Accepted: 24 May 2017

\begin{abstract}
Biomonitoring a stressed Kuwait Bay environment revealed a differential and collective transfer of mercury $(\mathrm{Hg})$ between the primary producer and primary and secondary consumers, in addition to possible $\mathrm{Hg}$ bioconcentrations and bioaccumulation in such marine organisms that attributed harmful effects to humans at the tertiary level of the food chain. Selected live samples were collected from five bay sites and exposed for $96 \mathrm{~h}$ and $30 \mathrm{~d}$ in aquarium tanks. Samples analyzed by direct mercury analyzer (detection limit of $0.0015 \mathrm{ng}^{-1} \mathrm{~g}^{-1}$ ) revealed $\mathrm{Hg}$ concentrations in the sequence of Barbatia helblingii $>$ Acanthopagrus berda $>$ phytoplankton $>$ zooplankton at sites IV $>$ V $>$ III $>$ I $>$ II during the summer and winter seasons, respectively. Bioaccumulation factor (BAF) was $>1$ in most of their trophic transfer, although Hg-BAF was $<1$ in a few trophic levels. Seasonal variations, anthropogenic sources, vestiges of $\mathrm{Hg}$ from the shut-down chlor-alkali plant, urbanization, slow water current, and nutrient upwelling attributed to the persistent $\mathrm{Hg}$ accumulation in the marine ecosystem. Since $\mathrm{Hg}$ is a ubiquitous pollutant in the bay, their transfer through the medium, diet, and net accumulation in higher predators is of importance to marine life and is a concern to tertiary consumers, including humans.
\end{abstract}

Keywords: bioconcentration, bioaccumulation, food chain, mercury

\section{Introduction}

Globally, the marine environment is facing tremendous ecological stress due to the influence of organic and inorganic pollutants that are dispersed in the aquatic system. Heavy metals contaminants are not completely biodegradable and have lengthy biological half-lives [12]. Many species in the marine environment are stressed due to diverse inputs of industrial, domestic, recreational, and agricultural pollutants, plus the effect of Gulf Wars oil spills in the past [3-4]. The seafood catch from the

*e-mail: abdul.buolayan@ku.edu.kw
Arabian Gulf is of commercial importance to the locals and export requisites. Specifically, Kuwait Bay caters 50$60 \%$ of the commercial seafood catch to the residents of Kuwait. Therefore, maintaining the quality of the marine environment is crucial for economic reasons [4].

Kuwait Bay is a semi-enclosed area that extends from the Arabian Gulf to the west. This bay has a shallow northern part inundated by mud flats, a central region with high nutrients, and sandy beaches in the southern shoreline region. Mercury pollution in Kuwait increased when the Salt Chlor-alkali plant (SCP) used mercury electrolytes and contaminated the marine ecosystem in the recent past. Mercury levels in the Kuwait marine ecosystem declined after the shutdown of the plant. However, rapid urbanization made it necessary to investigate total mercury in the 
marine environment. Mercury contamination was found to adversely affect organisms through absorption from the seawater, sediment, metal uptake, and bioaccumulation in the aquatic chain [5-9]. The finfish and shellfish provide useful tools for monitoring mercury concentrations and their impact on the aquatic environment [1, 8, 1011]. Earlier researchers [10-12] used atomic absorption spectrophotometry to detect mercury with sensitivity at $\pm 0.01 \mathrm{ppm}$. The precision of their results was limited due to interference by organic constituents. Based on these factors, the present study overcame the shortfalls of instrumental detection limits by using a direct mercury analyzer (DMA-80, Milestone, Italy) that could detect $\mathrm{Hg}$ from $0.0015 \mathrm{ng}^{-1} \mathrm{~g}^{-1}$ onwards in seawater and selected marine samples. This study determined the transfer of $\mathrm{Hg}$ from the primary producer (phytoplankton) to selected primary, secondary, and tertiary consumers, namely, zooplankton, shellfish (Barbatia helblingii), and finfish (Acanthopagrus berda) to validate the $\mathrm{Hg}$ bioconcentration (BCF) and bioaccumulation factors (BAF) in the food chain. BCF and BAF factors were determined by evaluating the initial $\mathrm{Hg}$ concentration in seawater to the mean $\mathrm{Hg}$ in the primary producer and the mean $\mathrm{Hg}$ concentrations between the secondary and primary consumers at the final exposure time. Furthermore, this study ensures that tertiary consumer-humans undertake precautionary measures regarding seafood consumption.

\section{Experimental}

\section{Seawater}

Using a Van Dorn water sampler, seawater replicates collected in sterile polystyrene containers in an icebox from five sites of the Kuwait Bay (Fig. 1) were transported to the laboratory. Total mercury $(\mathrm{Hg})$ in seawater during

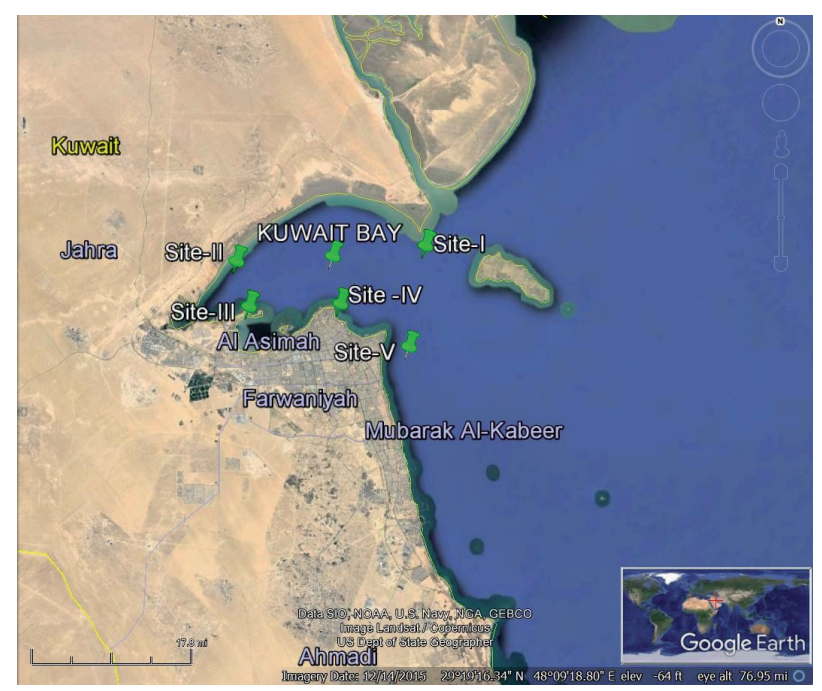

Fig. 1. Sampling sites of Kuwait Bay, Kuwait.

Site I: Subiyah, Site II: Khazma, Site III: Doha, Site IV: Kuwait Towers, Site V: Salmiya
2016-17 was tested in the direct mercury analyzer (DMA80, Milestone, Italy).

\section{Trophic Level I: Phytoplankton}

Phytoplankton was collected twice every month during 2016-17 using a plankton net (size $20 \mu \mathrm{m}$ and 30 $\mu \mathrm{m}$ ) towed by a boat at 0.2 knot speed from five Kuwait Bay sites. Storage, preservation, identification, and segregation of culture facilities were carried out in the laboratory following the standard methods [13-16]. The seasonal $\mathrm{Hg}$ concentrations variation in most common phytoplankton (dinoflagellates and diatoms) from five Kuwait Bay sites were initially determined. Three batches of phytoplankton replicates were categorized in this study to determine:

a. Hg concentrations in phytoplankton from five Kuwait bay sites.

b. The toxicity of $\mathrm{Hg}$ concentrations $\left(0.5,1.0,1.5 \mathrm{ng}^{-1}\right)$ at $\mathrm{LC}_{5}, \mathrm{LC}_{15}, \mathrm{LC}_{50}$ in the laboratory to validate $96 \mathrm{~h}$ $\mathrm{BCF}$ and $\mathrm{BAF}$ exposure.

c. BAF at $30 \mathrm{~d}$ exposure to test their effective accumulation in the marine food chain [17-18].

Details are schematically represented (Fig. 2). The criterion continuous concentration (CCC) given by the national recommended ambient water quality criteria is $0.94 \mu \mathrm{g} \cdot \mathrm{l}^{-1}[15]$. Phytoplankton concentrations exposure was equivalent to 2.46 to 3.39 times the $\mathrm{CCC}$ values. Phytoplankton was grown in F-medium following the standard method [16]. Phytoplankton exposed for $96 \mathrm{~h}$ toxicity and $30 \mathrm{~d}$ bioaccumulation tests followed the standard methods [19].

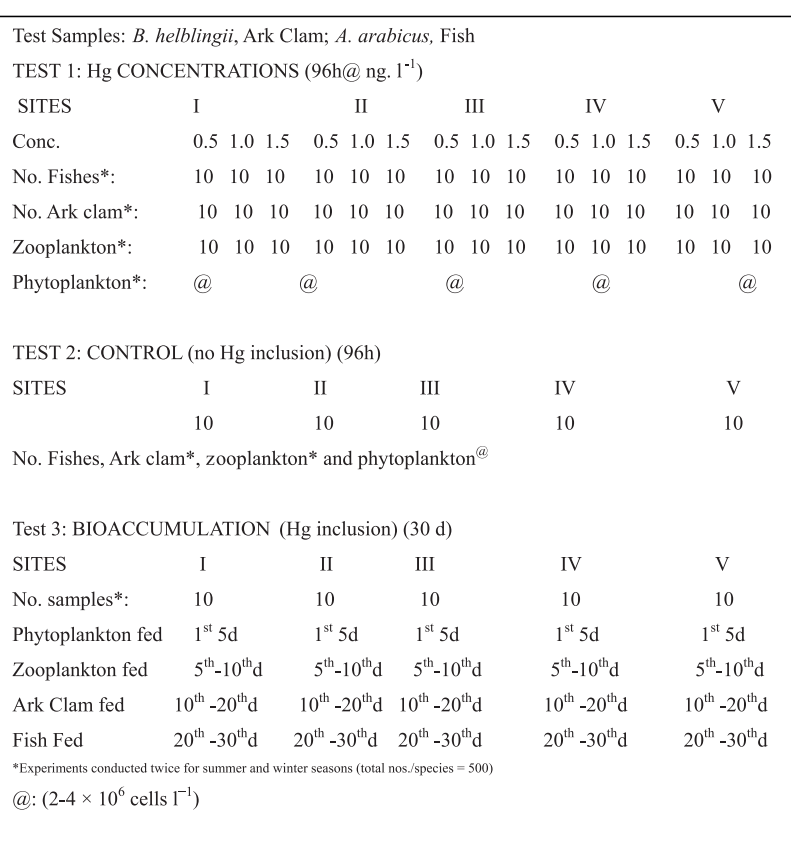

Fig. 2. Schematic representation of $\mathrm{Hg}$ toxicity and bioaccumulation tests.

Site I: Subiyah, Site II: Khazma, Site III: Doha, Site IV: Kuwait Towers, Site V: Salmiya 


\section{Trophic Level II: Zooplankton}

Zooplankton was collected from five Kuwaiti marine sites using a nitex net $(100 \mu \mathrm{m})$. The density of zooplankton was constantly maintained. The cultured zooplankton were fed with $\mathrm{Hg}$-exposed phytoplankton $\left(2-4 \times 10^{6}\right.$ cells $\left.\mathrm{L}^{-1}\right)$ two times per day for $96 \mathrm{~h}$ and days 5-10 during the $30 \mathrm{~d}$ bioaccumulation tests, respectively (Fig. 2).

\section{Trophic Level III: Mollusc-Barbatia helblingii (Ark Clam)}

This study collected replicates of Barbatia helblingii (Ark clam), from five Kuwait Bay sites, each measuring $20.0 \mathrm{~g} \pm 2 \mathrm{~g}$ and $35 \mathrm{~mm} \pm 5 \mathrm{~mm}$, weight and length, respectively. A toxicity test was modified to determine site- and seasonal-wise analyses [20-21]. The different $\mathrm{Hg}$ concentrations (as in trophic level I) and ethically compliant by the local statutory bodies elicited responses to this species at $\mathrm{LC}_{5} \mathrm{LC}_{15}$, and $\mathrm{LC}_{50}$. Biometric characteristics of $B$. helblingii were monitored and $\mathrm{Hg}$ concentrations determined by the DMA-80 analyzer. Workflow determining the $96 \mathrm{~h}$ and $30 \mathrm{~d}$ exposure following the earlier methods [22-23] are schematically represented (Fig. 2).

\section{Trophic Level IV: Fish-Acanthopagrus berda}

Acanthopagrus berda fish caught from five Kuwait Bay sites were immediately transported to the laboratory. A. berda fish representing the five sites each, with similar total length and weight $(18 \mathrm{~cm} \pm 2 \mathrm{~cm}$ and $55 \mathrm{~g} \pm 5 \mathrm{~g}$, respectively) were acclimated for $72 \mathrm{~h}$ in five aquarium tanks $(1,0001)$ containing filtered seawater $\left(27^{\circ} \mathrm{C}\right.$, salinity $39 \%$, $\mathrm{pH} 8.0$, and dissolved oxygen $>7 \mathrm{mg}^{-1}$ ) following the earlier methods [24-26]. The fish were fed daily to satiation with brine shrimp without $\mathrm{Hg}$ concentrations [25]. After $72 \mathrm{~h}$, the fish were not fed and gut depurated before the feeding experiments. Toxicity and bioaccumulation tests on these fish followed the earlier methods [27-30], and as described for B. helblingii $96 \mathrm{~h}$ and $30 \mathrm{~d}$.

\section{Hg Analysis}

Mercury in seawater, phytoplankton cultured cells $\left(96^{\text {th }} \mathrm{h}\right)$, zooplankton (w/v), mollusc (body tissues), and fish (10 each) homogenized whole body parts (unlike the normal procedure in using the gills, liver, and muscle tissues), were analyzed from the $\mathrm{Hg}$-exposed $(0.5,1.0$, 1.5 ng. $\left.\mathrm{g}^{-1}\right)$ concentrations as well, plus bioaccumulation studies (30 d) using the DMA-80 [31-34]. Quality control was assured following the use of blanks, controls, and standard reference materials from BCR, IAEA, NIST, and NRC (CRM-414 phytoplankton powder), (MA-A-1/ TM copepod), (SRM:1566b oyster tissue), and (CRM: DORM-2 dogfish muscle) [35-36]. Sample recovery (>95\%) to that of the standard reference materials were alone considered as the benchmark for quality assurance tests. Bioconcentration (BCF) and bioaccumulation (BAF) evaluated from the whole-body burden yielded the trophic transfer of $\mathrm{Hg}$ in the marine food chain [18]. $\mathrm{BCF}$ and $\mathrm{BAF}$ were determined by the following equation [18]:

$$
\mathrm{BCF}=\frac{\mathrm{Hg} \text { concentration in phytoplankton }}{\mathrm{Hg} \text { concentration in seawater }}
$$

$$
\mathrm{BAF}=\frac{\mathrm{Hg} \text { concentration in secondary consumers }}{\mathrm{Hg} \text { concentration in primary consumer }}
$$

\section{Results and Discussion}

\section{Hg Concentrations in Seawater}

Total $\mathrm{Hg}$ concentrations in seawater from the five sites of Kuwait Bay varied from $0.13 \mathrm{ng} \cdot \mathrm{l}^{-1}$ to $0.32 \mathrm{ng} \cdot \mathrm{l}^{-1}$ with a mean concentration of $\mathrm{Hg}\left(0.22 \mathrm{ng}^{-1}\right)$ during 2016-17. This was within the concentrations compared to the $\mathrm{Hg}$ levels observed by earlier investigators [23, 31-32]. This was also lower than $0.94 \mu \mathrm{g} \cdot \mathrm{l}^{-1}$ - the $\mathrm{Hg}$ criterion continuous concentration (CCC) in natural seawater [35] (Fig. 3). This study on three experimental $\mathrm{Hg}$ concentrations (Fig. 2 ) in the laboratory revealed a mean $\mathrm{Hg}$ loss of $82 \%$ in the control seawater without phytoplankton, which was attributed to the organic complexion or precipitation process. Site-wise observations revealed $\mathrm{Hg}$ concentrations in seawater in the order of magnitude collected from sites $\mathrm{V}>\mathrm{IV}>\mathrm{III}>\mathrm{I}>\mathrm{II}$ (Fig. 3). The high $\mathrm{Hg}$ concentrations in the sequence of sites $\mathrm{V}$ and IV indicated the past effect of salt chlor-alkali plants besides the present influence of discharges from desalination, thermal, power plants, industrial and domestic wastes, sedimentation, stagnation, and single-flow direction of Shatt Al-Arab River water mixing from the north to the south of Kuwait Bay. As the Bay water is characterized by restricted exchange with

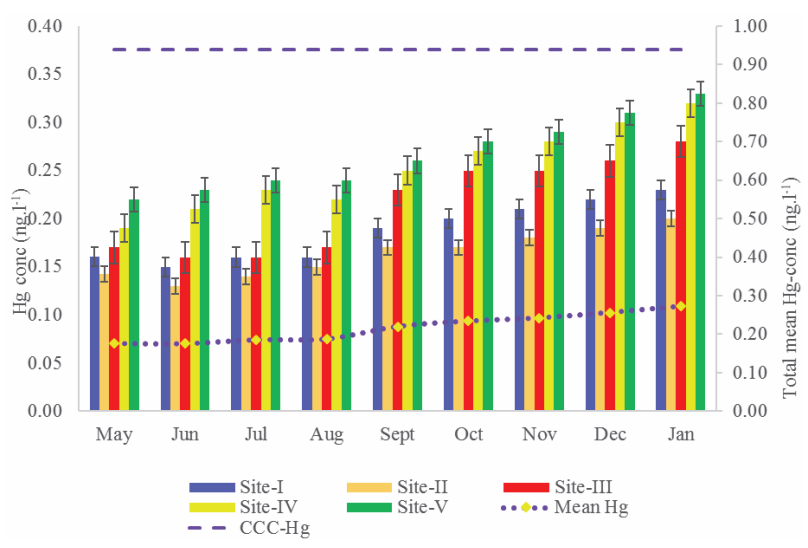

Fig. 3. Mercury concentrations in seawater from Kuwait Bay. CCC-Hg: Criterion Continuous Concentration for Hg (EPA, 2004). Site I: Subiyah, Site II: Khazma, Site III: Doha, Site IV: Kuwait Towers, Site V: Salmiya 


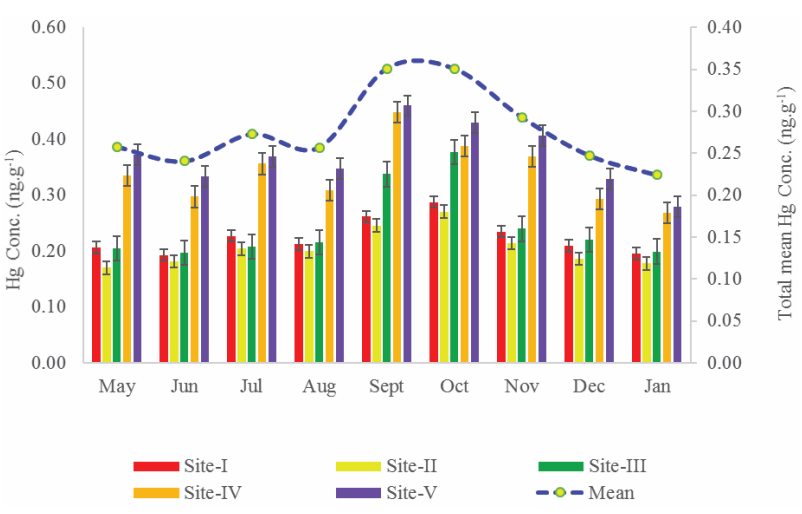

Fig. 4. Mercury concentrations in phytoplankton from Kuwait Bay.

Site I: Subiyah, Site II: Khazma, Site III: Doha, Site IV: Kuwait Towers, Site V: Salmiya the open sea, the chances of coastal and catchment habitat destruction and biodiversity loss was observed with significant environmental damage from pollution, thus supporting the views of [20-21, 23]. A gradual increase of $\mathrm{Hg}$ concentrations in seawater was observed during the winter compared to summer (Fig. 3). This is attributed to the low absorption of $\mathrm{Hg}$ concentrations by phytoplankton due to the slow photosynthesis process, precipitation, and low water current mixing in the winter. The above factors were validated statistically by ANOVA, indicating a significant difference between site-wise and season-wise $\mathrm{Hg}$ concentrations in seawater (Table 1). Such factors agreed with earlier studies [28].

\section{Hg Concentrations in Phytoplankton (Level I)}

The mean $\mathrm{Hg}$ concentrations in phytoplankton collected from the five sites of Kuwait Bay ranged

Table 1. Site- and season-wise ANOVA of Hg concentrations in seawater for the primary producer and consumers.

\begin{tabular}{|c|c|c|c|c|c|}
\hline Source of Variation & SS & df & $\mathrm{F}$ & P-value & F crit \\
\hline \multicolumn{6}{|c|}{$\mathrm{Hg}$ in seawater from nature } \\
\hline Site-wise & 0.067 & 4 & 113.93 & 0.0001 & 2.66 \\
\hline Season-wise & 0.052 & 8 & 44.77 & 0.0001 & 2.24 \\
\hline Error & 0.005 & 32 & & & \\
\hline Total & 0.125 & 44 & & & \\
\hline \multicolumn{6}{|c|}{$\mathrm{Hg}$ in phytoplankton from nature } \\
\hline Site-wise & 0.193565 & 4 & 88.85759 & $7.36 \times 10^{-17}$ & 2.66 \\
\hline Season-wise & 0.084487 & 8 & 19.39219 & $3.06 \times 10^{-10}$ & 2.24 \\
\hline Error & 0.017427 & 32 & & & \\
\hline Total & 0.295479 & 44 & & & \\
\hline \multicolumn{6}{|c|}{$\mathrm{Hg}$ in zooplankton from nature } \\
\hline Site-wise & 0.027 & 4 & 24.42 & $2.46 \times 10^{-09}$ & 2.66 \\
\hline Season-wise & 0.111 & 8 & 50.05 & $6.3 \times 10^{-16}$ & 2.24 \\
\hline Error & 0.009 & 32 & & & \\
\hline Total & 0.147 & 44 & & & \\
\hline \multicolumn{6}{|c|}{$\mathrm{Hg}$ in ark clam mollusc from nature } \\
\hline Site-wise & 0.181 & 4 & 10.07 & $2.15 \times 10^{-05}$ & 2.66 \\
\hline Season-wise & 0.426 & 8 & 11.82 & $1.19 \times 10^{-07}$ & 2.24 \\
\hline Error & 0.144 & 32 & & & \\
\hline Total & 0.751 & 44 & & & \\
\hline \multicolumn{6}{|c|}{$\mathrm{Hg}$ in seabream fish from nature } \\
\hline Site-wise & 0.247 & 4 & 51.51 & $1.69 \times 10^{-13}$ & 2.66 \\
\hline Season-wise & 0.272 & 8 & 28.42 & $1.92 \times 10^{-12}$ & 2.24 \\
\hline Error & 0.038 & 32 & & & \\
\hline Total & 0.558 & 44 & & & \\
\hline
\end{tabular}


Table 2. BCF and BAF in nature and the experimental marine food chain.

\begin{tabular}{|c|c|c|c|c|}
\hline No. & Relationships & $\begin{array}{c}\text { Mean-Hg } \\
\text { Kuwait Bay sites }{ }^{\dagger}\end{array}$ & $\begin{array}{c}\text { BCF/BAF }(96 \mathrm{~h}) \text { nature; } \\
\text { experimental }\left(0.5,1.0,1.5 \text { ng. } .^{-1}\right) \\
\text { Hg exposure } \\
\end{array}$ & $\begin{array}{c}\text { BCF/BAF }(30 \mathrm{~d}) \text { nature }^{\dagger} ; \\
\text { experimental }\left(0.5,1.0,1.5 \mathrm{ng}^{1 \mathrm{l}^{-1}}\right) \\
\mathrm{Hg} \text { exposure }\end{array}$ \\
\hline 1. & **Seawater & $0.22 \pm 0.01$ & $0.25^{\dagger} 0.24,0.27,0.31$ & Not Applicable \\
\hline 2. & $* *$ Seawater $\rightarrow$ Phytoplankton & $0.28 \pm 0.06$ & $1.29^{\dagger}, 0.65,0.69,0.91$ & $2.74,2.63,3.09$ \\
\hline 3. & *Phytoplankton $\rightarrow$ Zooplankton & $0.24 \pm 0.02$ & $0.74^{\dagger}, 0.58,0.79,1.03$ & $0.81,1.33,1.30$ \\
\hline 4. & $\begin{array}{l}* \text { Zooplankton } \rightarrow \text { Ark clam } \\
(\text { Phytoplankton } \rightarrow \text { Ark clam })\end{array}$ & $0.38 \pm 0.03$ & $\begin{array}{c}1.92^{\dagger}, 0.97,1.60,2.13 \\
\left(1.42^{\dagger}\right)\end{array}$ & $1.94,1.95,2.08$ \\
\hline 5. & $\begin{array}{l}* \text { Ark clam } \rightarrow \text { Fish } A \text {. berda } \\
\quad(* \text { Zooplankton } \rightarrow \text { Fish }) \\
\quad(* \text { phytoplankton } \rightarrow \text { Fish })\end{array}$ & $0.33 \pm 0.04$ & $\begin{array}{c}0.88 \dagger \\
1.67 \dagger 0.86,1.54,2.21 \\
1.18 \dagger\end{array}$ & $\begin{array}{l}0.89,1.02,1.10 \\
1.72,1.75,1.98\end{array}$ \\
\hline & $\begin{array}{c}\text { *Entire Food Chain (Nos. 2-4) } \\
\text { Phytoplankton to A. berda }\end{array}$ & $0.29 \pm 0.02$ & $0.44^{\dagger}$ & 1.43 \\
\hline
\end{tabular}

**BCF: bioconcentration factor- initial $\mathrm{Hg}$ concentration in seawater to the mean $\mathrm{Hg}$ in phytoplankton, $\uparrow$ : samples analyzed in natural environment, *BAF: bioaccumulation factor- mean $\mathrm{Hg}$ concentrations at the final exposure time in the organisms

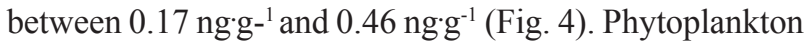

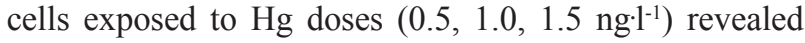
2.46 to 3.35 times higher concentrations than the $\mathrm{Hg}$ exposed phytoplankton that ranged from $0.45 \mathrm{ng} \cdot \mathrm{g}^{-1}$ to $1.51 \mathrm{ng} \cdot \mathrm{g}-{ }^{1}$. Hg concentration recovery was higher at $0.5 \mathrm{ng}^{-1} \mathrm{l}^{-1}(55 \%)$ compared to the $\mathrm{Hg}$ recovery at $1.0 \mathrm{ng}^{-1} \mathrm{l}^{-1}(27 \%)$ and $1.5 \mathrm{ng} \cdot \mathrm{l}^{-1}(18 \%)$ exposure concentrations. In other words, phytoplankton exposed for $96 \mathrm{~h}$ at $1.5 \mathrm{ng} \cdot \mathrm{l}^{-1}$ revealed the maximum $\mathrm{Hg}$ concentrations loss $(82 \%)$ at $1.5 \mathrm{ng} \cdot \mathrm{l}^{-1}$ test dose from that of the $\mathrm{Hg}$ concentrations in the naturally collected phytoplankton. Thus, low assimilation of $\mathrm{Hg}$ concentrations in the phytoplankton was observed and possibly found in line with the earlier observations of [29, 33]. Site-wise $\mathrm{Hg}$ concentrations in phytoplankton were in the sequence such as the observations of $\mathrm{Hg}$ levels in seawater. However, the season-wise $\mathrm{Hg}$ concentrations in phytoplankton were high during the summer, which is attributed to the necessity of sunlight and temperature in the photosynthetic process in relation to their abundance in the five respective sites. This was also statistically validated (Table 1). High $\mathrm{Hg}$ accumulation in the phytoplankton was confirmed by a high bioconcentration factor $(\mathrm{BCF})$. The mean $\mathrm{BCF}$ in phytoplankton were higher in the three $\mathrm{Hg}$-exposed test concentrations when compared to the Hg-BCF collected from nature (Table 2).

The mean $96 \mathrm{~h}$ uptake rate at $1.5 \mathrm{ng} \cdot \mathrm{l}^{-1,1.0} \mathrm{ng} \cdot \mathrm{l}^{-1}$, and $0.5 \mathrm{ng} \cdot \mathrm{l}^{-1}$ of $\mathrm{Hg}$ exposure concentrations in phytoplank-

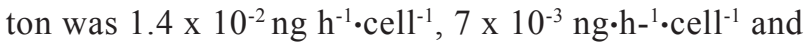

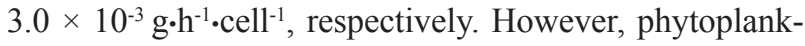
ton revealed an uptake of $2.9 \times 10^{-3} \mathrm{ng} \cdot \mathrm{h}^{-1} \cdot \mathrm{cell}^{-1} \mathrm{Hg}$ concentrations in the natural environment that were considerably lower than the phytoplankton subjected to $\mathrm{Hg}$ exposure in the laboratory, indicating the low assimilation of $\mathrm{Hg}$ by phytoplankton in nature. These results were in line with earlier studies $[12,23,31]$.

\section{Hg in Zooplankton (Level II)}

The most common zooplankton collected throughout the year was considered for this study to determine unbiased $\mathrm{Hg}$ concentrations. The mean $\mathrm{Hg}$ concentrations in zooplankton collected from the five Kuwait Bay sites were between $0.08 \mathrm{ng}^{-1} \mathrm{~g}^{-1}$ and $0.32 \mathrm{ng}^{-1}$. Exposure of (96 h) $\mathrm{Hg}$ concentrations at $1.5 \mathrm{ng} \cdot \mathrm{g}^{-1}$ revealed $84 \%$ loss, indicating a poor transfer of $\mathrm{Hg}$ in the zooplankton. This agreed with earlier studies [25, 33-34].

Site-wise observations revealed peak $\mathrm{Hg}$ concentrations in zooplankton in the sequence of sites $\mathrm{V}>\mathrm{IV}>\mathrm{III}>\mathrm{I}>\mathrm{II}$ (Fig. 5). Seasonally, the mean $\mathrm{Hg}$ concentrations in zooplankton were observed high during the peak summer season (August-October) compared to the onset of winter (November-January). Reasons may be attributed to the influence of the metabolic rate and the assimilation of $\mathrm{Hg}$ from phytoplankton by zooplankton during the summer. This agreed with earlier findings [2, 9, 33]. During the

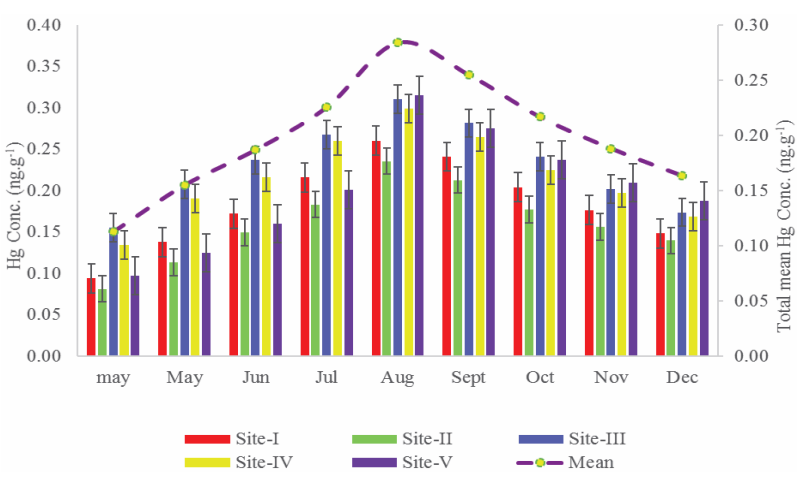

Fig. 5. Mercury concentrations in zooplankton from Kuwait Bay.

Site I: Subiyah, Site II: Khazma, Site III: Doha, Site IV: Kuwait Towers, Site V: Salmiya 


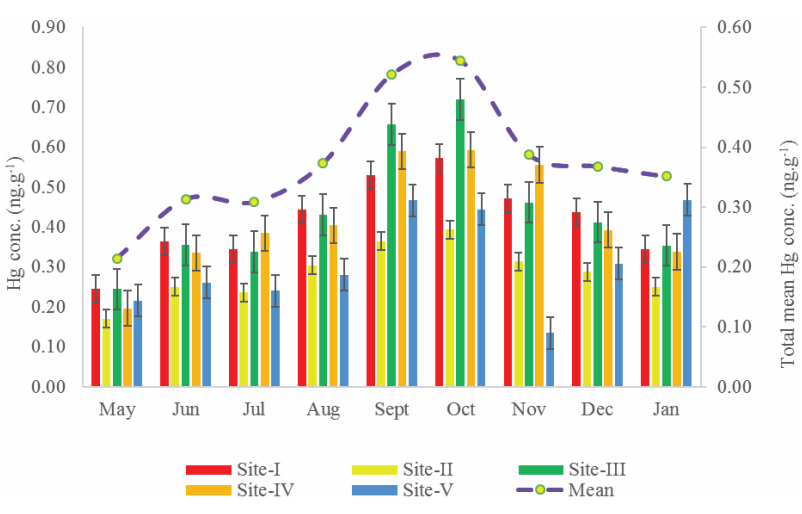

Fig. 6. Mercury concentrations in B. helblingii ark clam from Kuwait Bay.

Site I: Subiyah, Site II: Khazma, Site III: Doha, Site IV: Kuwait Towers, Site V: Salmiya

onset of winter (November-January), low water current, low phytoplankton abundance, and the photosynthesis process in Kuwait Bay was found to elevate the overall $\mathrm{Hg}$ accumulation in the zooplankton compared to the $\mathrm{Hg}$ concentration during the onset of the mid-summer season (May-July) (Fig. 5). The $96 \mathrm{~h}$ test of $\mathrm{Hg}-\mathrm{BAF}$ at 0.5 and $1.0 \mathrm{ng} \cdot 1^{-1}$ exposure indicated a low bioaccumulation ability or effective filtration and excretion by the zooplankton (Table 2). However, at 1.0 and $1.5 \mathrm{ng} \cdot \mathrm{l}^{-1} \mathrm{Hg}$ exposure, the BAF in zooplankton was observed to be higher than the Hg-BAF in phytoplankton, indicating a positive bioaccumulation process over a $30 \mathrm{~d}$ period of time (Table 2).

\section{Hg in Barbatia helblingii (Level III)}

The mean $\mathrm{Hg}$ concentrations in the whole tissue of Barbatia helblingii (ark clam) varied from $0.17 \mathrm{ng}^{-1}$ to $0.72 \mathrm{ng} \mathrm{g}^{-1}$ (Fig. 6). This was higher than the concentrations reported earlier in other species [5, 8-10, 20, 26]. Seasonal and site-wise results showed a similar pattern of $\mathrm{Hg}$ concentrations as observed in zooplankton. B. helblingii exposed for $96 \mathrm{~h}$ revealed a mean of $0.97 \mathrm{ng} \mathrm{g}^{-1}, 1.60 \mathrm{ng} \mathrm{g}^{-1}$,

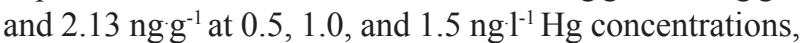
respectively, in their whole-body tissues. The mean $\mathrm{Hg}$ $\mathrm{BAF}$ was found to increase from phytoplankton and zooplankton in B. helblingii in the natural environment (Table 2), evidencing the bioaccumulation process. Low $\mathrm{BAF}$ at $0.5 \mathrm{ng} \mathrm{g}^{-1} \mathrm{Hg}$ exposure suggests $B$. helblingii species have mechanisms to detoxify and self-regulate uptake metal over a short exposure period $(96 \mathrm{~h}$ ) (Table 2). These mechanisms support the earlier views of metallothioneins and phosphate granule production $[22$, 30].

\section{Hg in Acanthopagrus berda (Level IV)}

The mean $\mathrm{Hg}$ concentrations in Acanthopagrus berda fish ranged $0.2-0.45 \mathrm{ng}^{-1}$ (Fig. 7), which was in line with earlier studies $[3,6,11]$. Fish exposed to three different concentrations showed an increasing trend of

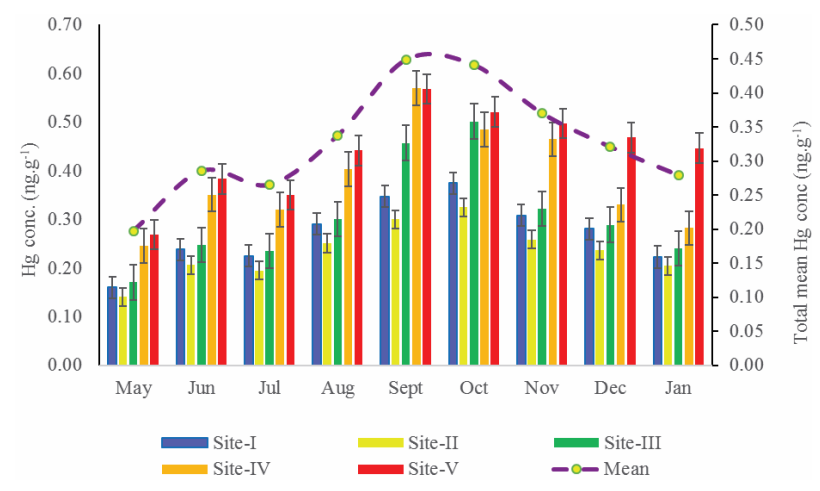

Fig. 7. Mercury concentrations in $A$. berda fish from Kuwait Bay.

Site I: Subiyah, Site II: Khazma, Site III: Doha, Site IV: Kuwait Towers, Site V: Salmiya

$\mathrm{Hg}$ concentrations with $96 \mathrm{~h}$ exposure. The transfer of $\mathrm{Hg}$ concentrations between $A$. berda (predator) and molluscs, zooplankton (prey), and phytoplankton (diet) evaluated by regression analysis $\left(\mathrm{r}^{2}=0.95,0.91\right.$, and $\left.0.66 \mathrm{p}<0.05\right)$, validated the strongly dependent $\mathrm{Hg}$ concentrations in the predator-prey relationship. The regression analysis $\left(\mathrm{r}^{2}=0.66\right)$ evaluated between $A$. berda and phytoplankton indicated their weak dependency and the least $\mathrm{Hg}$ concentration uptake by the fish. Hg levels in the different prey decreased the availability with a bio-diminution effect of accumulated $\mathrm{Hg}$ to upper trophic levels [25, 30, 36]. Seasonal and site-wise analysis in $A$. berda showed a similar trend of $\mathrm{Hg}$ concentrations as observed in the zooplankton (Fig. 7). The mean Hg-BAF transfer between A. berda and zooplankton in nature was high compared to the Hg-BAF in the phytoplankton and ark clam (Table 2), indicating a high $\mathrm{Hg}$ accumulation and low $\mathrm{Hg}$ assimilation efficiency in the former and later species, respectively. $\mathrm{Hg}$-BAF was high in $30 \mathrm{~d}$ tests, indicating a positive bioaccumulation process in $A$. berda. Studies evidenced $\mathrm{Hg}$ concentrations distribution in the gills and liver of fish as the main organ for the detoxification and elimination of metals in fish, although different body parts reported high $\mathrm{Hg}$ concentrations by earlier investigators [26-27]. This study analyzed the whole-body parts of the $A$. berda fish to maintain the evenness and uniform distribution of samples. Thus differential Hg concentrations in the body tissues and organs were not investigated.

\section{Conclusions}

In an overall view, this study revealed a significant trophic transfer of $\mathrm{Hg}$ concentrations from the primary producer (phytoplankton) to the secondary (zooplankton) and tertiary consumers (mollusc and fish), although the percentage of $\mathrm{Hg}$ transfer between the secondary and tertiary consumer at certain trophic levels was diminutive because of bioaccumulation, the environment, and ocean dynamics. However, in light of commercial seafood resources, the high $\mathrm{Hg}$ concentrations in seawater, 
residues from the chlor-alkali plant in the past, and the discharge of domestic and industrial wastes into the marine environment in the present represent a risk to human health. Because $\mathrm{Hg}$ is not an essential trace element for humans, their presence in the human body, even at low concentrations, attributes deleterious effects. Thus, this study recommends consumption of marine organisms with precautionary measures.

\section{Acknowledgements}

The authors thank the Research Administration of Kuwait University for financial support through the grant SC-03/15.

\section{References}

1. MARZIEH H., MARAGHEH M.G., SHAMAMI M.A., BEHGAR M. Evaluate of heavy metal concentration in shrimp (Penaeus semisulcatus) and crab (Portunus pelagicus) with INAA method. Springer Plus 2, 72, 2013.

2. POLAK-JUSZCZAK L. Bioaccumulation of mercury in the trophic chain of flatfish from the Baltic Sea. Chemos. 89 (5), 585, 2012

3. FREIJE A.M. Heavy metal, trace element and petroleum hydrocarbon pollution in the Arabian Gulf: Review. J. Assoc. Arab Univ. Basic Appl. Sci. 17, 90, 2014.

4. SHEPPARD C., AL-HUSAINI M., AL-JAMALI F., AL-YAMANI F., BALDWIN R. The Gulf: A young sea in decline. Mar. Pollut. Bull. 60, 13, 2010.

5. AL-FARRAJ S., EL-GENDY A.H., ALYAHYA H., EL-HEDENY M. Heavy metals accumulation in the mantle of the common cuttlefish Sepia pharaonis from the Arabian Gulf. Australian J. Basics and Appl. Sci. 5 (6), 897, 2011.

6. HAJEB P., JINAP S., ISMAIL A., FATIMAH A.B, JAMILAH B., RAHIM M.A. Assessment of mercury level in commonly consumed marine fishes in Malaysia. Food Contr. 20 (1), 79, 2009.

7. BURGER J. GOCHFELD M. Selenium and mercury molar ratios in saltwater fish from new jersey: individual and species variability complicate use in human health fish consumption advisories. Environ. Res. 114, 12-23, 2012.

8. ALYAHAYA H., EL-GENDY A.H., AL-FERAJ S., EL-HEDENY M. Evaluation of heavy metals pollution in the Arabian Gulf using the clam Meritrix meritrix Linnaeus, 1758. Wat. Air Soil Pollut. 214, 499, 2011.

9. BU-OLAYAN A.H., THOMAS B.V. Dispersion model and bioaccumulation factor validating trace metals in sea bream inhabiting wastewater drain outfalls. Int. J. Environ. Sc. Tech. 11 (3), 795, 2014.

10. TARIQUE Q., BURGER J., REINFELDER J.R. Metal concentrations in organs of the Clam Amiantis umbonella and their use in monitoring metal contamination of Coastal sediments. Wat. Air Soil Pollut. 223 (5), 2125, 2012.

11. AL-MUGHAIRI S., YESUDHASON P., AL-BUSAIDI M., AL-WAILI A., AL-RAHBI W.A.K., AL-MAZROOEI N., AL-HABSI S.H. Concentration and exposure assessment of mercury in commercial fish and other seafood marketed in Oman. J. Food Sci. 78, T1082-T1090, 2013.
12. YUAN X., YANG G., DING Y., LI X., ZHAN XUEFANG Z., ZHAO Z., DUAN Y. An effective analytical system based on a pulsed direct current microplasma source for ultra-trace mercury determination using gold amalgamation cold vapor atomic emission spectrometry. Spectrochim. Acta Part B: Atom.Spectr. 93 (1), 1, 2014.

13. SOURNIA A. Phytoplankton manual. United Nations Educational, Scientific and Cultural Organization (UNESCO), Paris. 344, 1978.

14. APHA. Standard methods for the examination of water and wastewater, RICE E.W., BAIRD R.B., EATON A.D., CLESCERI L.S. editors, $22^{\text {nd }}$ Edition, American Public Health Association, 2012.

15. USEPA National Recommended Water Quality Criteria - Aquatic Life Criteria Table. https://www.epa.gov/wqc/ national - recommended - water-quality - criteria - aquaticlife - criteria-table. 11, 2004.

16. TOMAS C.R., HASLE G.R. Identifying marine phytoplankton. $10^{\text {th }}$ Edition, San Diego, Academic Press, 2010. ISBN: $9780126930184012693018 \mathrm{X}$

17. OLMEDO P., PLA A.., HERNÁNDEZ A.F., BARBIER F., AYOUNI L., GIL F. Determination of toxic elements (mercury, cadmium, lead, tin and arsenic) in fish and shellfish samples. Risk assessment for the consumers. Environ. Internat. 59, 63-72, 2013.

18. COSTANZA J, LYNCH D.G., BOETHLING R.S., ARNOT J.A. Use of the bioaccumulation factor to screen chemicals for bioaccumulation potential. Environ. Toxicol. 31 (10), 2012.

19. MAGDALENA B., KOBOS J. Mercury concentration in phytoplankton in response to warming of an autumn - winter season. Environ. Pollut. 215, 38, 2016.

20. SAFAHIEH A., MAHMOODI M., NIKPOUR Y., GHANEMI K. Polycyclic aromatic hydrocarbons concentration in soft tissue of Ark clam (Barbatia helblingii) along Bushehr coasts (summer). $2^{\text {nd }}$ International Conference on Environmental Engineering and Applications. IPCBEE, IACSIT Press, Singapore. 17, 199, 2011.

21. WARD E.J., KACH D.J. Marine aggregates facilitate ingestion of nanoparticles by suspension-feeding bivalves. Mar. Environ. Res. 68 (3), 137-142, 2009.

22. AARON N.A., GYASI-ANTWI1 D., NYAABA R.A. Biomonitoring of non-essential heavy metals concentrations in the tono-irrigation dam using mussel tissues. Amer. J. Environ. Protect. 2 (6), 121, 2013.

23. AGUILAR C.A., MONTALVO C., RODRI'GUEZ L., CERO'N J.G., CERO'N R.M. American oyster (Crassostrea virginica) and sediments as a coastal zone pollution monitor by heavy metals. Internat. J. Environ. Sci. Technol. 9, 579, 2012.

24. AFSHAN S., ALI S., AMEEN U.S., FARID M., BHARWANA S.A., HANNAN F., AHMAD R. Effect of different heavy metal pollution on fish. Res. J. Chem. Environ. Sci. 2 (1), 74, 2014.

25. MOORE A.B.M., BOLAM T., LYONS B.P., ELLIS J.R. Concentrations of trace elements in a rare and threatened coastal shark from the Arabian Gulf (smooth-tooth blacktip Carcharhinus leiodon). Mar. Pollut. Bull. 100 (2), 646, 2015.

26. BERVOETS L., KNAPEN D., DE JONGE M., VAN CAMPENHOUT K., BLUST R. Differential hepatic metal and metallothionein levels in three feral fish species along a metal pollution gradient. PLoS One 8 (3), e60805, 2013.

27. EL-MOSELHY KH.M., OTHMAN A.I., EL-AZEM H.A, EL-METWALLY M.E.A. Bioaccumulation of heavy metals 
in some tissues of fish in the Red Sea, Egypt. Egypt J. Basic Appl. Sci. 1 (2), 97, 2014.

28. MATHEWS T., FISHER N.S. Evaluating the trophic transfer of cadmium, polonium, and methylmercury in an estuarine food chain. Environ. Toxicol. Chem. 27, 1093, 2008.

29. OUÉDRAOGO O., CHÉTELAT J., AMYOT M. Bioaccumulation and trophic transfer of mercury and selenium in African sub-tropical fluvial reservoirs food webs (Burkina Faso). PLoS ONE 10 (4), e0123048, 2015.

30. CARDOSO P.G., PEREIRA E., DUARTE A.C., AZEITEIRO U.M. Temporal characterization of mercury accumulation at different trophic levels and implications for metal biomagnification along a coastal food web. Mar. Pollut. Bull. 87 (1-2), 15, 39, 2014.

31. BRAVO A.G., COSIO C., AMOUROUX D., ZOPFI J., CHEVALLEY P.A., SPANGENBERG J.E., UNGUREANU V.G., DOMINIK J. Extremely elevated methyl mercury levels in water, sediment and organisms in a Romanian reservoir affected by release of mercury from a chlor-alkali plant. Wat. Res. 49, 391, 2014.
32. ZHIJIA C., ZHANG X., WANG Z. Elemental mercury in coastal seawater of Yellow Sea, China: Temporal variation and air-sea exchange. Atm. Environ. 45 (1), 183, 2011.

33. GOSNELL K.J., MASON R.P. Mercury and methylmercury incidence and bioaccumulation in plankton from the central Pacific Ocean. Mar. Chem. 177 (5), 772, 2015.

34. FOX A.L., HUGHES E.A., TROCINE R.P., TREFRY J.H., SCHONBERG S.V., MCTIGUE N.D., LASORSA B.K., KONAR B., COOPER L.W. Mercury in the northeastern Chukchi Sea: Distribution patterns in seawater and sediments and biomagnification in the benthic food web. Deep Sea Res. Part II: Topical Studies Oceanogr. 102, 56-67, 2014.

35. EPA National recommended water quality criteria for priority toxic pollutants. EPA office of science and technology, updated 22 December, 2016, https://www.epa.gov/wqc/ national-recommended-water-quality-criteria-aquatic lifecriteria -table. 22, 2004.

36. PENGLASE S., HAMRE K., ELLINGSEN S. Selenium and mercury have a synergistic negative effect on fish reproduction. Aquat Toxicol. 149, 16, 2014. 